\begin{tabular}{|c|c|c|}
\hline & Our Nature & $\begin{array}{l}\text { ISSN: 1991-2951 (Print) } \\
\text { ISSN: 2091-2781 (Online) }\end{array}$ \\
\hline $\begin{array}{l}\text { Nature Conservation \& } \\
\text { Health Care Council } \\
\text { Blocthoga Nopod }\end{array}$ & Journal homepage: http://nepjol.info/index.php/ON & (c) ${ }_{\mathrm{BY}}$ (6) \\
\hline
\end{tabular}

\title{
Fish Assemblage Structure and Environmental Correlates in Nepal's West Rapti River, Banke
}

\author{
Sujata Chaudhary ${ }^{1}$, Jash Hang Limbu*2, Suren Subba ${ }^{3}$, Jeevan Kumar Gurung ${ }^{4}$, Naresh \\ Pandey $^{1}$ and K. Deepak Singh ${ }^{1}$
}

\author{
${ }^{1}$ Central Department of Zoology, Tribhuvan University, Kirtipur, Kathmandu, Nepal \\ ${ }^{2}$ DAV College faculty of science and humanities, Tribhuvan University, Lalitpur, Nepal \\ ${ }^{3}$ Dhankuta Multiple Campus, Tribhuvan University, Dhankuta, Nepal \\ ${ }^{4}$ Damak Multiple Campus, Tribhuvan University, Damak, Jhapa, Nepal \\ Corresponding Email: limbujash@gmail.com
}

\begin{abstract}
The spatial and temporal variations of fish assemblages in rivers and streams of Nepal are poorly understood. So, the present study aimed to explore the spatial and temporal variations of fish assemblage structure in Nepal's West Rapti River. The data were collected during autumn, winter and spring seasons, from October 2018 to April 2019. Fish samples were collected using cast net of $12 \mathrm{~mm}$ mesh size. A total of 28 species belonging to 7 orders, 10 families and 19 genera were recorded during the study. The analysis of similarity (ANOSIM) showed no significant difference among the stations and seasons. Based on cluster analysis, two major clusters were observed. The similarity percentage (SIMPER) analysis delineated that Cabdio morar (C14, 13.63\%), Barilius bendelensis (C11, 10.32\%), Gogangra viridescens (C22, 7.85\%), Salmostoma phulo (C17, 7.74\%), Labeo gonius (C5, 7.53\%), Gagata cenia (C23, 6.45\%), Garra gotyla (C6, 5.87\%) and Labeo dyocelius (C2, 5.62\%) were the most contributing species. The Canonical Correspondence Analysis (CCA) distinctly showed that the environmental variables dissolved oxygen, $\mathrm{pH}$, carbon-dioxide, and water temperature play an essential role in shaping the fish assemblage structure of West Rapti River.
\end{abstract}

Keywords: Environmental variables, Fish assemblage, Fish diversity, Rapti River, Spatio-temporal

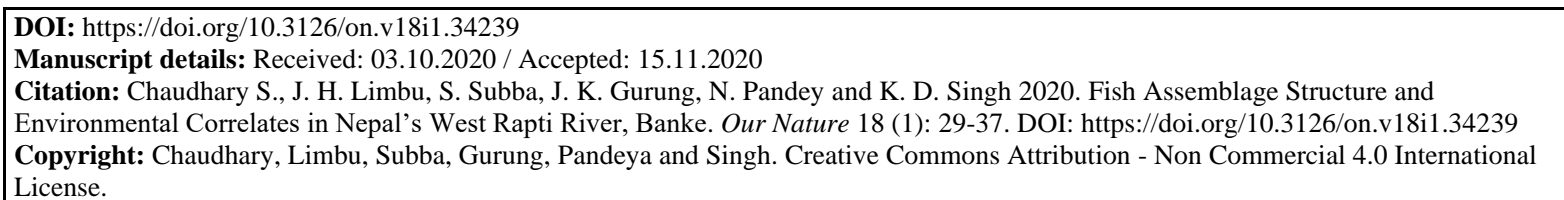

\section{Introduction}

Fish assemblage variation is function of the many inter-connecting factors, including hydrol-ogic regime, geo-climatic region, species comp-osition, biotic versus abiotic regulation, channel type, disturbance history and frequency (Gross-mann et al., 1998). It has been widely reported that the distribution and abundance of fish species are strongly regulated by environmental factors (Tejerina et al., 1998; Brown, 2000). These factors include topographical characte-ristics (Platts, 1979), climate (Eaton and Scheller, 1996), hydrological regime (Poff and Allan, 1995), riparian land use (Lammert and Allan, 1999), and water physical-chemical variables like dissolved oxygen and $\mathrm{pH}$ (Matthews, 1998). These abiotic parameters have short-term and long-term influences on the structure of fish assemblages (Gasith and Resh, 1999). Beside the abiotic factors, biotic factors like predation and competition also affect fish assemblages via direct and indirect mechanisms (Jackson et al., 2001). Characterizing the factors that affect fish assemblages is beneficial for river management and fish preservation. Similar studies on fish-habitat relationships have 


\section{Our Nature | December 2020 | 18 (1): 28-37}

been carried out in South America (Fialho et al., 2008), North America (Feyrer and Healey, 2003), Europe (Gondinho, 2000) and Africa (Ibanez, 2007), but are still lacking for Asia (Shahnawaz et al., 2010).

Rapti River is one of the most important River in Mid- Western part of the country, which provides good habitat for fishes and other aquatic organisms. Despite a number of studies related with aquatic diversity from different parts of Nepal, little study has been conducted on the fish assemblage structure in West Rapti River Banke. Therefore, this study was designed to investigate the spatio-temporal variation in fish assemblage structure of West Rapti River, Banke Nepal.

\section{Materials and method}

Study area

The present study was carried out in the West Rapti River, Banke. The West Rapti River is one of the main drainage of Mid-western region which originates from highland of Rolpa, Pyuthan and some parts of Argakhachi flowing through Mahabharat range to low land of Dang and Banke district and at last discharges into the India. It originates from above the elevation of $3523 \mathrm{~m}$ near Rangon. The River originates as Madikhola then joins with Lungrikhola and Jhimrukkhola near Airawati and flows to Terai plains known as West Rapti River. Sit khola, Arunkhola, Ransinkhola are major small tributaries of the West Rapti River. Total catchment area is about $6,320 \mathrm{Sq} \cdot \mathrm{km}^{15}$. The study area starts from Siktaghat at $28^{\circ} 01^{\prime} 48.94 " \mathrm{~N}$ $81^{\circ} 58^{\circ} 09.19^{\prime \prime} \mathrm{E}$ to Saipur at $28^{\circ} 02^{\prime} 56.23^{\prime \prime N} \mathrm{~N}$ $81^{\circ} 54^{\prime} 09.29 " \mathrm{E} 12 \mathrm{~km}$ along West Rapti River (Fig. 1).The present study was carried out from October 2018 to April 2019.

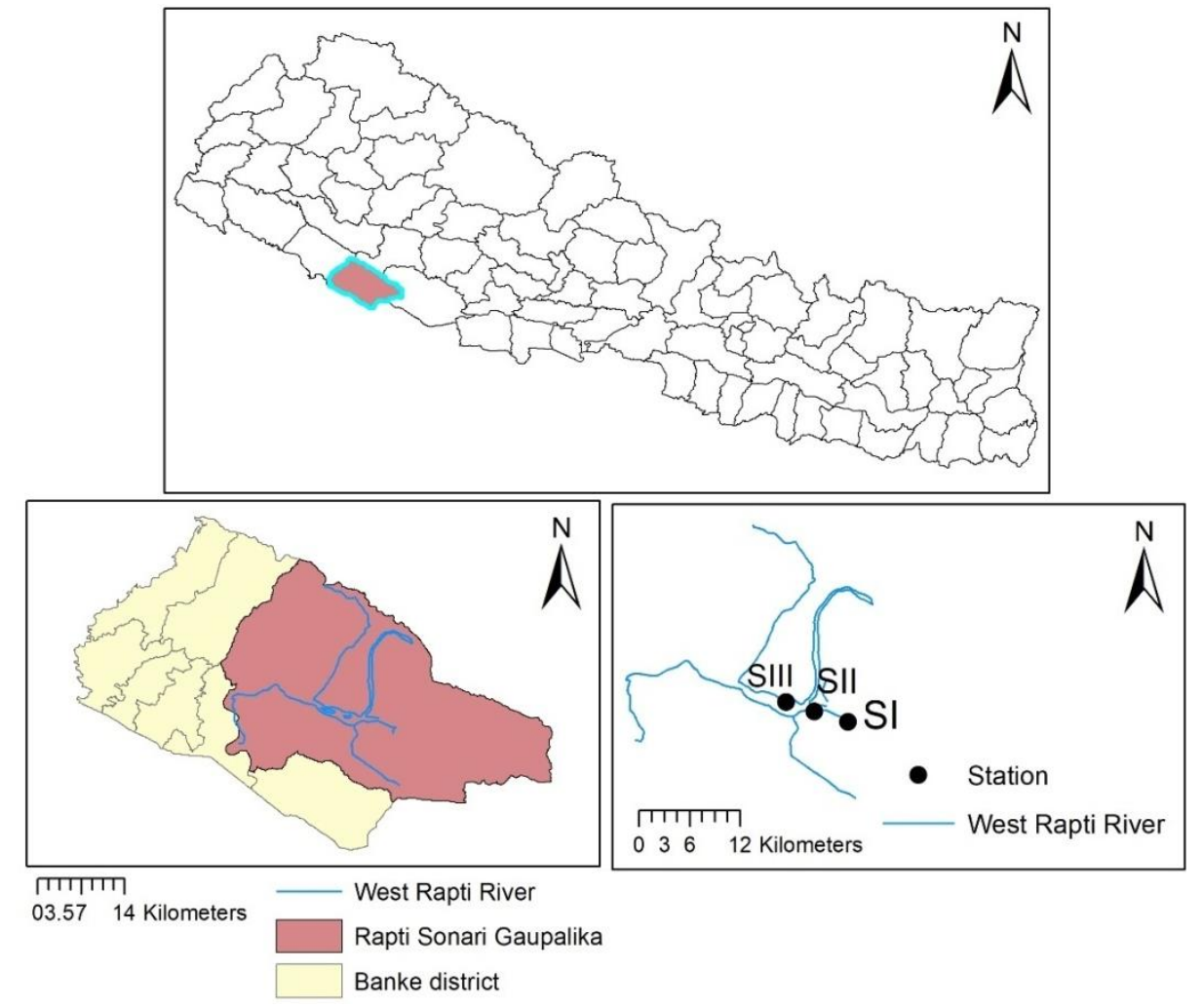

Figure 1. Map of study area

\section{Selection of sampling station}

A preliminary survey was done prior to the selection of sampling stations. Three sampling stations were selected below and above the Sikta irrigation dam. Station-I $\left(28^{\circ} 01^{\prime} 48.94^{\prime \prime N} 81^{\circ} 58^{\prime}\right.$ 09.19"E; 180m asl) is at Siktaghat above the Sikta irrigation dam. This area is also under Banke National Park. So, fishing is restricted to local people except licensed fishermen. Station-II $\left(28^{\circ} 02^{\prime} 41.86^{\prime \prime} \mathrm{N} 81^{\circ} 56^{\prime} 19.18^{\prime \prime} \mathrm{E}\right.$; $168 \mathrm{~m}$ asl) is below the Sikta irrigation dam and cattle grazing land. This area is under Banke National Park. Station-III $\left(28^{\circ} 03^{\prime} .06^{\prime \prime} \mathrm{N} 81^{\circ} 54^{\prime} 12.79^{\prime \prime} \mathrm{E} ; 159\right.$ asl $)$ is near Saipur village and quarrying of stone and sand is done from this area so it is mostly disturbed area.

\section{Fish collection, preservation and identification}

The fishes were collected from each sampling station by employing local fishermen in three 


\section{Our Nature | December 2020 | 18 (1): 28-37}

different seasons by using cast net of $5 \mathrm{~kg}$ weight having $5 \mathrm{~m}$ length and $20 \mathrm{~m}$ breadth with $12 \mathrm{~mm}$ mesh size. Sampling was done from 8 am to $10 \mathrm{am}$. The collected fish samples were photographed and were preserved in $10 \%$ formalin solution and brought to the Central Department of Zoology (CDZ), Tribhuvan Univ-ersity, Nepal for further identification. Identifi-cation of the samples was done by the help of standard references (Talwar and Jhingram, 1991; Jayaram, 2010; Shrestha, 2019).

\section{Analysis of environmental variables}

Water samples were collected during morning time (9:00 am to 10:00 am) and analyzed once every three months. Water temperature $\left({ }^{\circ} \mathrm{C}\right)$ was measured by the help of a mercury thermometer. $\mathrm{pH}$ was measured by using a calibrated $\mathrm{pH}$ meter (HI 98107, HANNA Instrument). Free $\mathrm{CO}_{2}$ was determined by titration using $0.05 \mathrm{~N}$ of $\mathrm{NaOH}$ and phenolphthalein as an indicator. Dissolved oxygen (DO) was estimated by Winkler's idiometric method.

\section{Data analysis}

Detrended Correspondence Analysis (DCA) was performed to determine whether Redundancy Analysis (RDA) or Canonical Correspondence Analysis (CCA) would be appropriate model to describe the association between fish species and variables. The axis length and eigen value obtained from DCA suggested that the linear model of CCA was more applicable. Therefore, a direct multivariate ordination method (Terbraak, 1986), based on a linear response of species to environmental gradients was applied by using vegan library in $\mathrm{R}$ (Oksanenm et al., 2015). Oneway analysis of similarity (ANO-SIM) was used to determine the significance of spatial and temporal variation of fish assemblage structure (Clarke, 1993). Similarity percentages analysis (SIMPER) was executed to observe the percentage of similarity in temporal scale (Clarke, 1993).

\section{Results \\ Fish community composition}

A total number of 821 individuals were collected during the study, which belonged to 7 orders, 10 families, 19 genera and 28 species (Table 1, figure 5).The Cyprinidae was the most species-rich family (9 genera and 18 species) (Table 2), which is same to other water bodies in Nepal. he seven most copious fish species comprised $(75.88 \%)$ of the total catch, i.e., Cabdio morar (369 individuals, 59.22\%), Barilius bendelisis (54 individuals, $8.66 \%)$, Salmostoma phulo (47 individuals, 7.54\%), Barilius barila (42 individuals, 6.74\%), Botia lohachata (42 individuals, 6.74\%), Puntius sophore (37 individuals, 5.93\%), and Labeo dyocelius (32 individuals, 5.13\%) (Table 1).

Table 1. Spatial and Temporal variation of fish assemblage structure of West Rapti River.

\begin{tabular}{|c|c|c|c|c|c|c|c|c|c|c|c|}
\hline \multirow{2}{*}{ S.N. } & \multirow{2}{*}{ Name of species } & \multicolumn{3}{|c|}{ Autumn } & \multicolumn{3}{|c|}{ Winter } & \multicolumn{3}{|c|}{ Spring } & \multirow{2}{*}{ Tota } \\
\hline & & $\mathrm{I}$ & II & III & $\mathrm{I}$ & II & III & $\mathrm{I}$ & II & III & \\
\hline 1. & Labeo frimbiatus $(\mathrm{C} 1)$ & 2 & 2 & 3 & 2 & 1 & 2 & 3 & - & 2 & 17 \\
\hline 2. & Labeo dyocheilus (C2) & 5 & 10 & - & 3 & 4 & 1 & 1 & 5 & 3 & 32 \\
\hline 3. & Labeo bata (C3) & 2 & 1 & 1 & 2 & 3 & 2 & 2 & 6 & 1 & 20 \\
\hline 4. & Labeo boga $(\mathrm{C} 4)$ & 4 & - & 2 & - & 2 & 1 & - & 4 & 2 & 15 \\
\hline 5. & Labeo gonius (C5) & - & - & - & - & - & - & 5 & 10 & 6 & 21 \\
\hline 6. & Garra gotyla (C6) & - & - & - & 4 & 2 & - & 5 & 4 & 7 & 22 \\
\hline 7. & Garra rupecula $(\mathrm{C} 7)$ & - & - & - & 2 & 1 & - & - & - & - & 3 \\
\hline 8. & Puntius sophore (C8) & 6 & 5 & 3 & 3 & 7 & 5 & 3 & - & 5 & 37 \\
\hline 9. & Puntius terio (C9) & - & 2 & 3 & 1 & - & 2 & - & 2 & 3 & 13 \\
\hline 10. & Tor putitora $(\mathrm{C} 10)$ & - & - & - & 1 & - & - & - & - & - & 1 \\
\hline 11. & Barilius bendelensis (C11) & 12 & 10 & 9 & 8 & 5 & 7 & 2 & - & 1 & 54 \\
\hline 12. & Brilius barila $(\mathrm{C} 12)$ & 4 & 7 & 5 & 5 & 4 & 2 & 5 & 4 & 6 & 42 \\
\hline 13. & Barilius vagra (C13) & 3 & 3 & 4 & 2 & 1 & 2 & - & 2 & - & 17 \\
\hline 14. & Cabdio morar (C14) & 30 & 35 & 42 & 40 & 41 & 39 & 45 & 47 & 50 & 369 \\
\hline 15. & Raiamas bola (C15) & - & - & - & - & - & - & 3 & 5 & 1 & 9 \\
\hline 16. & Rasbora danionius (C16) & - & - & - & - & - & - & 1 & - & - & 1 \\
\hline 17. & Salmostoma phulo (C17) & 10 & 7 & 5 & 11 & 6 & 3 & 2 & - & 3 & 47 \\
\hline 18. & Salmostoma acinaces (C18) & 5 & - & 2 & - & 2 & - & 1 & - & - & 10 \\
\hline 19. & Paracanthobotis botia (C19) & - & - & - & - & - & - & 2 & - & 1 & 3 \\
\hline 20. & Lepidocephalichthys guntea (C20) & - & - & - & 1 & - & - & - & - & - & 1 \\
\hline 21. & Botia lohachata $(\mathrm{C} 21)$ & 5 & 4 & 2 & 6 & 3 & 2 & 8 & 5 & 7 & 42 \\
\hline 22. & Gogangra viridescens (C22) & - & - & - & - & - & - & 5 & 7 & 10 & 22 \\
\hline 23. & Gagata cenia $(\mathrm{C} 23)$ & - & - & - & - & - & - & 5 & 6 & 7 & 18 \\
\hline 24. & Xenentodon cancila (C24) & - & - & - & - & - & - & 1 & - & - & 1 \\
\hline 25. & Pseudombassis baculis(C25) & - & - & - & - & - & - & - & 1 & - & 1 \\
\hline 26. & Macrogonathus armatus (C26) & - & - & - & - & - & - & 1 & - & - & 1 \\
\hline 27. & Channa punctata (C27) & - & - & 1 & - & - & - & - & - & - & 1 \\
\hline 28. & Glosso gobiusgiuris (C28) & - & - & - & - & - & - & - & 1 & - & 1 \\
\hline 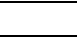 & otal & & & & & & & & & & 821 \\
\hline
\end{tabular}


Our Nature | December 2020 | 18 (1): 28-37

Table 2. Systematic position of the fish collected from West Rapti River

\begin{tabular}{|c|c|c|c|c|}
\hline S.N & Order & Family & Genus & Species \\
\hline \multirow[t]{21}{*}{1.} & Cypriniformes & Cyprinidae & Labeo & L. frimbiatus \\
\hline & & & & L. dyocheilus \\
\hline & & & & L.bata \\
\hline & & & & L.boga \\
\hline & & & & L.gonius \\
\hline & & & Garra & G.gotyla \\
\hline & & & & G.rupecula \\
\hline & & & Puntius & P. sophore \\
\hline & & & & P.terio \\
\hline & & & Tor & T. putitora \\
\hline & & & Brilius & B. bendelensis \\
\hline & & & & B. barila \\
\hline & & & & B. vagra \\
\hline & & & Cabdio & C. morar \\
\hline & & & Raiamas & R. bola \\
\hline & & & Rasbora & R. danionius \\
\hline & & & Salmostoma & S. acinaces \\
\hline & & & & S. phulo \\
\hline & & Nemacheilidae & Paracanthobotis & P. botia \\
\hline & & Cobitidae & Lepidocephalichthys & L. guntea \\
\hline & & Botiidae & Botia & B. lohachata \\
\hline \multirow[t]{2}{*}{2.} & Siluriformes & Sisoridae & Gogangra & G. viridescens \\
\hline & & & Gagata & G. cenia \\
\hline 3. & Beloniformes & Belonidae & Xenentodon & X. cancila \\
\hline 4. & Synbranchiformes & Mastacembelidae & Macrognathus & M. aral \\
\hline 5. & Perciformes & Ambassidae & Pseudombassis & P. baculis \\
\hline 6. & Anabantiformes & Channidae & Channa & C. punctata \\
\hline 7. & Gobiiformes & Gobiidae & Glossogobius & G. giuris \\
\hline
\end{tabular}

\section{Spatial and temporal relation of fisheries biodiversity}

The Canonical Correspondence Analysis (CCA) showed that the species of $\mathrm{C} 12, \mathrm{C} 2$, and $\mathrm{C} 4$ were positively correlated to water temperature while species of $\mathrm{C} 11, \mathrm{C} 17, \mathrm{C} 18, \mathrm{C} 13, \mathrm{C} 27, \mathrm{C} 1$ and $\mathrm{C} 6$ were positively related to dissolved oxygen and $\mathrm{pH}$ and negatively related to free-carbon dioxide.
Fish species of C7, C10 and C20 were not related to any environmental variables.C23, C22, C5, C15, C6, C14, C21, C19, C25, C28, C16, $\mathrm{C} 24, \mathrm{C} 26, \mathrm{C} 3$, and $\mathrm{C} 9$ were positively correlated to free-carbon dioxide and negatively related to dissolved oxygen and $\mathrm{pH}$ (Fig. 2).

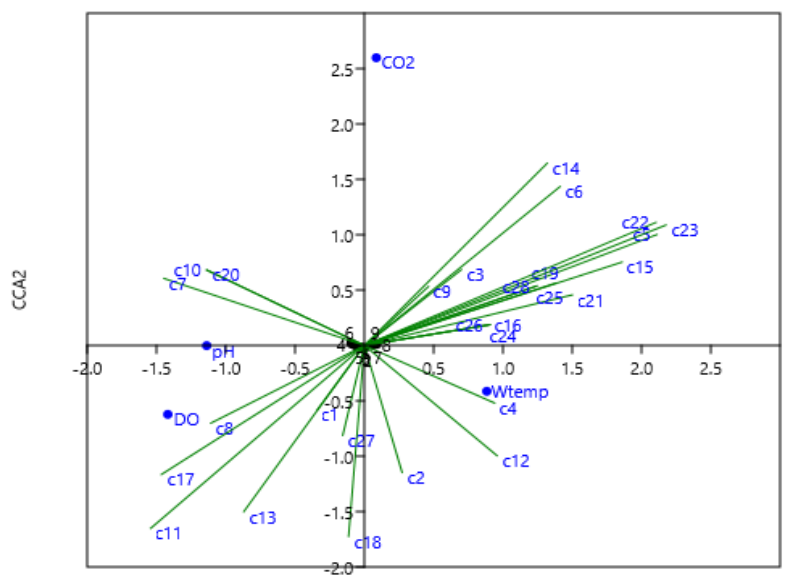

CCA1

Figure 2. Canonical Correspondence Analysis (CCA) ordination of fish assemblages and environmental variables of West Rapti River (for species code see table 1).

Based on similarity percentage (SIMPER) analysis the major contributing species are Cabdio morar (13.63\%), Barilius bendelensis (10.32\%), Gogangra viridescens (7.851\%), Salmostoma phulo 
Our Nature | December 2020 | 18 (1): 28-37

(7.749\%), Labeo gonius (7.537\%), Gagata cenia (6.453\%), Garra gotyla (5.874\%) and Labeo dyocheilus (5.625\%) (table 3).

Table3. Average similarity and discriminating fish using SIMPER analysis.

\begin{tabular}{|l|c|c|}
\hline \multicolumn{1}{|c|}{ Species } & Code & Contribution (\%) \\
\hline Cabdio morar & C14 & 13.63 \\
\hline Barilius bendelensis & C11 & 10.32 \\
\hline Gogangra viridescens & C22 & 7.851 \\
\hline Salmostoma phulo & C17 & 7.749 \\
\hline Labeo gonius & C5 & 7.537 \\
\hline Gagata cenia & C23 & 6.453 \\
\hline Garra gotyla & C6 & 5.874 \\
\hline Labeo dyocheilus & C2 & 5.625 \\
\hline Botia lohachata & C21 & 4.524 \\
\hline Puntius sophore & C8 & 3.852 \\
\hline Raiamas bola & C15 & 3.262 \\
\hline Barilius vagra & C13 & 3.136 \\
\hline Salmostoma acinaces & C18 & 2.907 \\
\hline Labeo boga & C4 & 2.885 \\
\hline Brilius ba rila & C12 & 2.733 \\
\hline Labeobata & C3 & 2.59 \\
\hline Puntius terio & C9 & 2.26 \\
\hline Labeo frimbiatus & C1 & 1.624 \\
\hline Garra rupecula & C 7 & 1.119 \\
\hline Paracanthobotis botia & C19 & 1.098 \\
\hline
\end{tabular}

Based on cluster analysis, two major clusters were observed. The first cluster contained station II and III with autumn and winter. The Second cluster showed station I with Spring (Fig. 3 and 4).

Cluster dendrogram with p-values (\%)

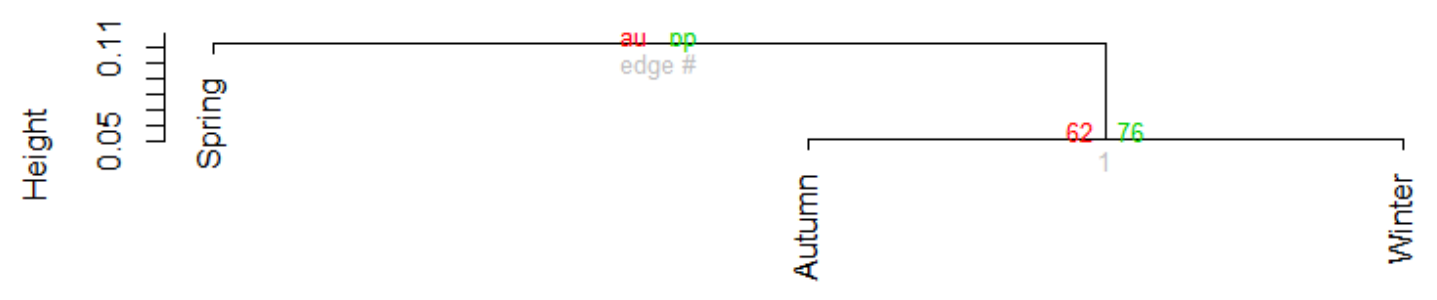

Distance: correlation

Cluster method: average

Figure 3. Dendrogram of cluster analysis comparing sampling seasons on the basis of fish assemblage.

Cluster dendrogram with p-values (\%)

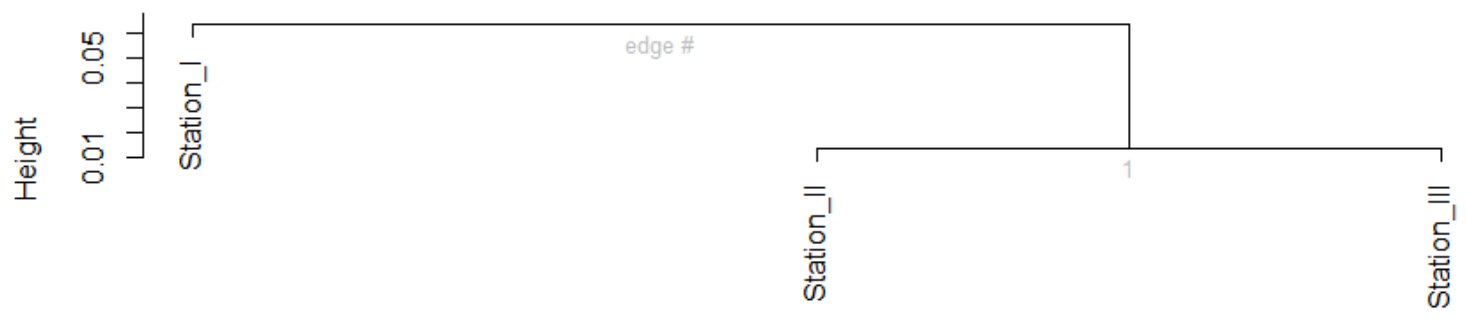

Distance: correlation

Cluster method: average

Figure 4. Dendrogram of cluster analysis comparing sampling stations on the basis of fish assemblage 
Our Nature | December 2020 | 18 (1): 28-37

The analysis of similarity (ANOSIM) revealed insignificant spatial variation among the three sampling sites (Table 4). The ANOSIM also showed insignificant seasonal variation in the fish assemblage among the sites (Table 5).

Table 4. Result of one way ANOSIM (significance levels) among different stations.

\begin{tabular}{|c|c|c|c|}
\hline Stations & I & II & III \\
\hline I & - & 0.8989 & 0.6984 \\
\hline II & 0.8989 & - & 0.4971 \\
\hline III & 0.698 & 0.4971 & - \\
\hline
\end{tabular}

Table 5. Result of one way ANOSIM (significance levels) among different seasons.

\begin{tabular}{|c|c|c|c|}
\hline Seasons & Autumn & Winter & Spring \\
\hline Autumn & - & 0.4032 & 0.0966 \\
\hline Winter & 0.4034 & - & 0.0958 \\
\hline Spring & 0.0966 & 0.0958 & - \\
\hline
\end{tabular}

\section{Discussion}

A total number of 28 species were reported during the study period. Among them are Cabdio morar, Barilius bendelensis, Gogangra viridescens, Salmostoma phulo, Labeo gonius, Gagata cenia, Garra gotyla, Labeo dyocheilus, Botia lohachata, Puntius sophore, Raiamas bola, Barilius vagra, Salmostoma acinaces, Labeo boga, Brilius barila, Labeo bata, Puntius terio, Labeo fimbriatus, Garra rupecula and Paracantho cobotis botia, each contributing more than $1 \%$ based on similarity percentage (SIMPER) analysis. The Cyprinidae was the most numerous family with 18 species which is consistent the findings of Limbu et al. (2016) and Yan et al. (2010). Limbu et al. (2019a), Limbu et al. (2019b) and Subba et al.(2017) reported 152, 9, 18 and 118 fish species from eastern Nepal, Bakraha River, Ratuwa River and Morang district. Pokharel et al. (2018) identified 24 species whereas Oli (2016) found 20 fish species from West Rapti River. In terms of spatial and temporal assemblage structure of fish, two major groups were indicated by BrayCurtis similarity cluster analysis in the West Rapti River. The first cluster consisted of stations I and II with autumn and winter. Second cluster consisted of station III with spring season. Based on ANOSIM, the fish assemblages in the West Rapti River showed no difference both in temporal and spatial scales. The finding was inconsistent with the finding of Yan et al. (2010).

Effects of environmental variable on species distributions were tested by Canonical Correspondence (CCA) analysis. Species located near the origin either do not show a strong relationship to any of the variables or are found at average values of environmental variables Marshall and Elliott (1998). In the present study, water temperature and dissolved oxygen were found to be pivotal variables to shape the fish assemblage structure of West Rapti River. Water temperature Kadye et al. (2007) and dissolved oxygen Limbu et al. (2019b) have been shown to influence fish assemblages. Besides, current velocity Yu and Lee (2002), depth Kadye et al. (2007), width Gerhard et al. (2003), substrata Vlach et al. (2005), altitude Magalhaes et al.(2002), conductivity $\mathrm{Yu}$ and Lee (2002) and climate Ferreira et al. (2009) have all been also shown to influence fish assemblages structure. Out of 28 fish species, eight species viz; Tor putitora, Rasbora danionius, Lepidocephalichthys guntea, Xenentodon cancila, Pseudambassis baculis, Macrogonathus aral, Channa punctataand Glossogobius giuris were recorded of only single individuals of each species. Tor putitora has been listed in endangered category (Shrestha, 2019) and was recorded from station I only. This is because this site is restricted area for fishing and is not affected by human activities whereas in station II and III, people have destroyed the habitat of aquatic organisms by extracting boulders, cobbles, pebbles and sand. Furthermore, as mentioned earlier, stations II and III, where local people graze their cattle might have negative impact for aquatic life, including fish. For instance, excreta of cattle and consequences of soil pollution due to grazing near the river bank may have adverse effects. The spatial and temporal variations of fish assemblages in rivers and streams of Nepal are poorly understood. Therefore, to better monitor, manage and conserve the Nepal's fisheries, there is an urgent need to update the information on the spatial and temporal scales of fish diversity, distribution pattern and community structure. 
Our Nature | December 2020 | 18 (1): 28-37

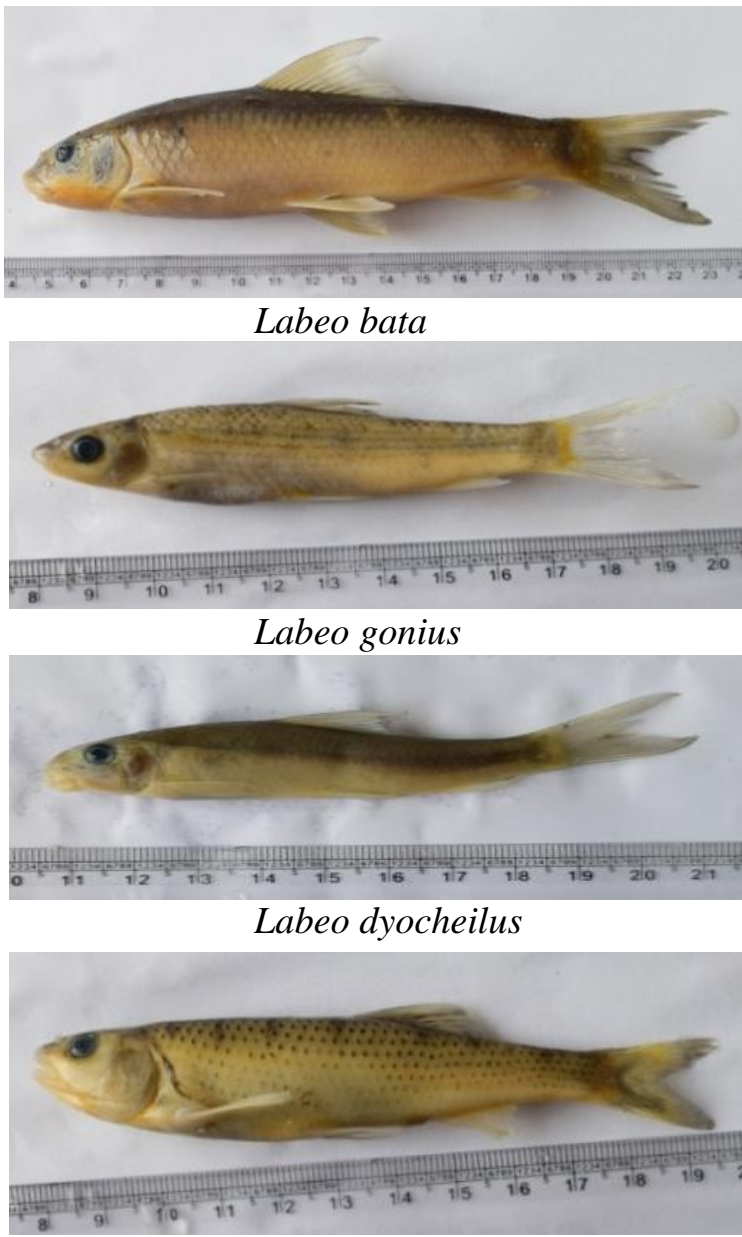

Barilius bendelensis

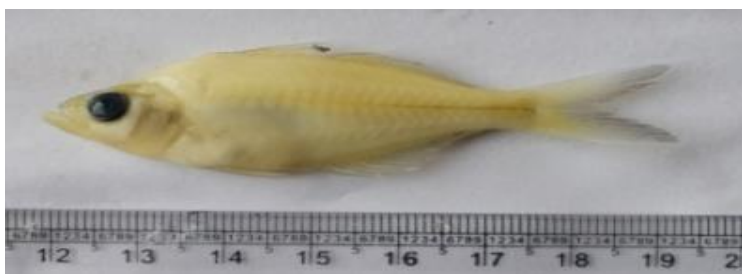

Pseudambassis baculis

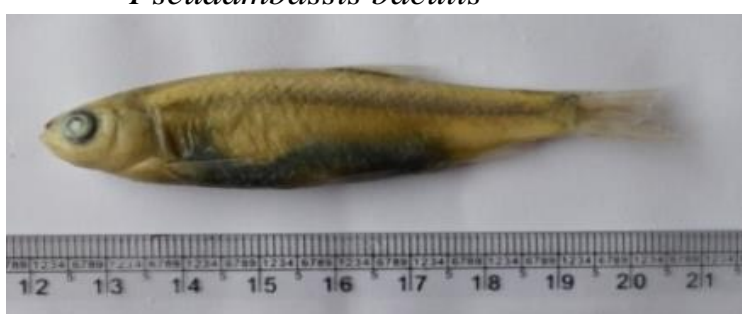

Glossogobiusgiuris

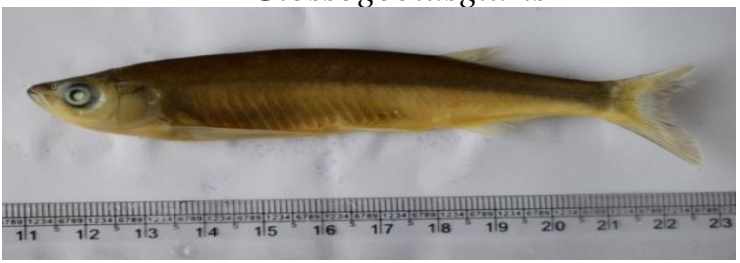

Salmostomaacinaces

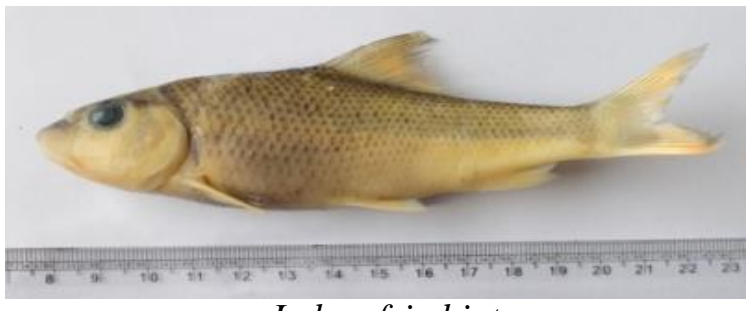

Labeo frimbiatus

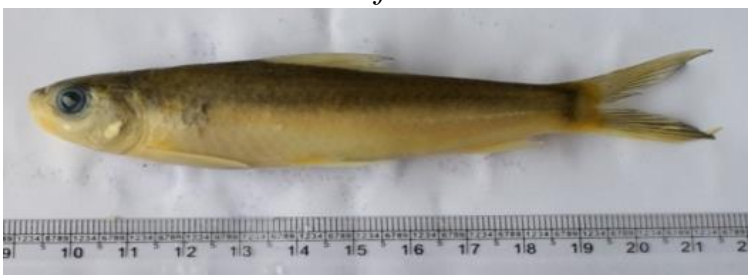

Labeo boga

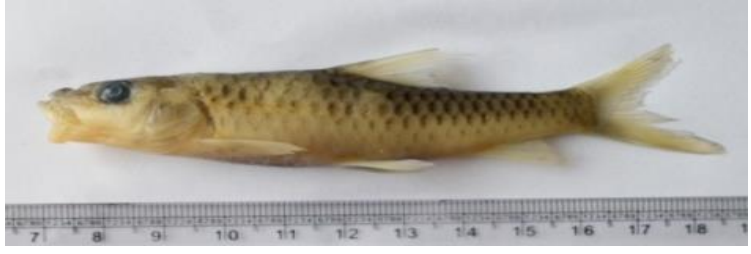

Tor putitora

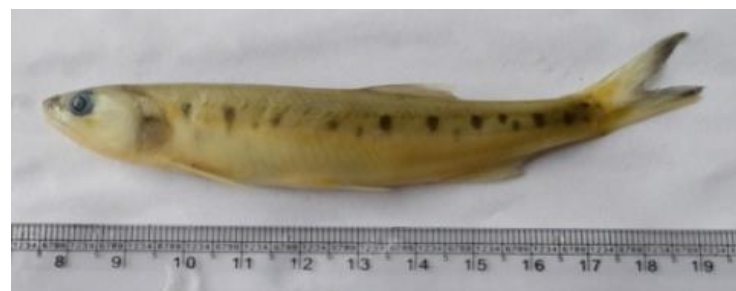

Raiamas bola

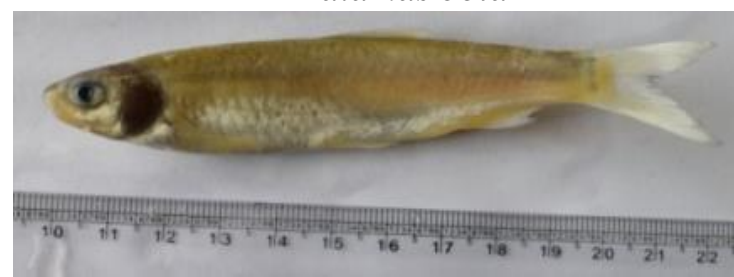

Cabdio morar

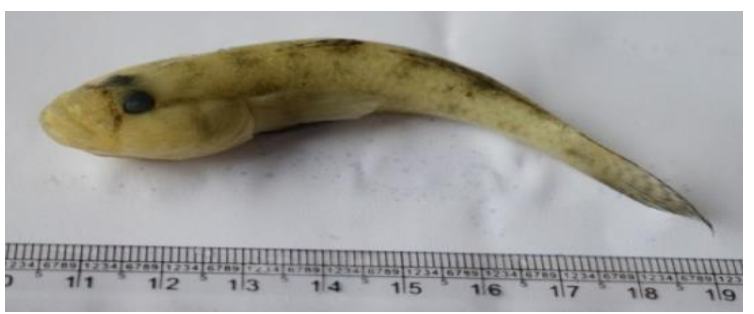

Salmostomaphulo

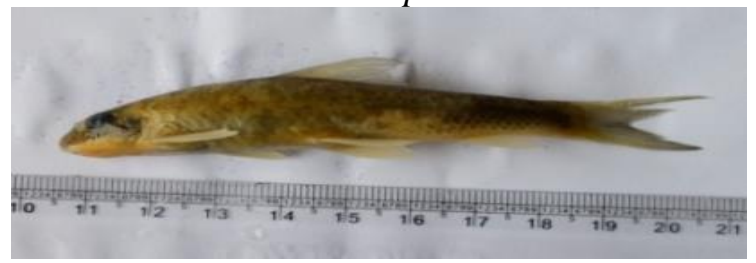

Garra rupecula 
Our Nature | December 2020 | 18 (1): 28-37

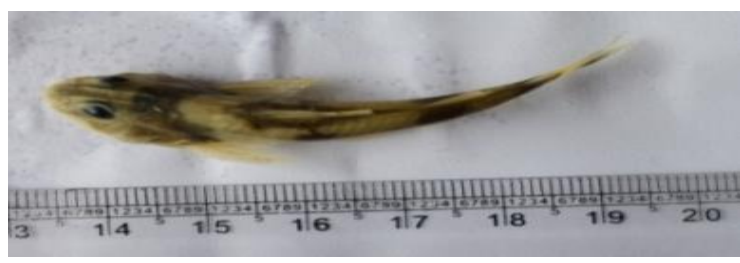

Gogangra viridescens

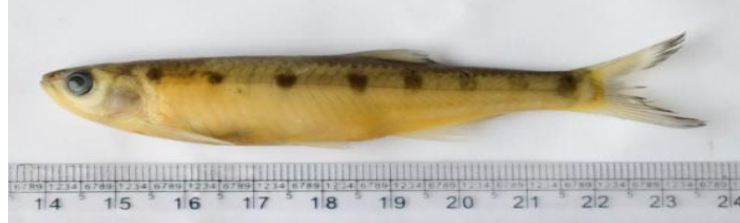

Barilius vagra

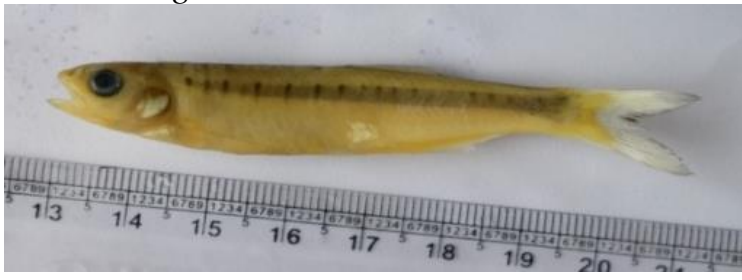

Barilius barila

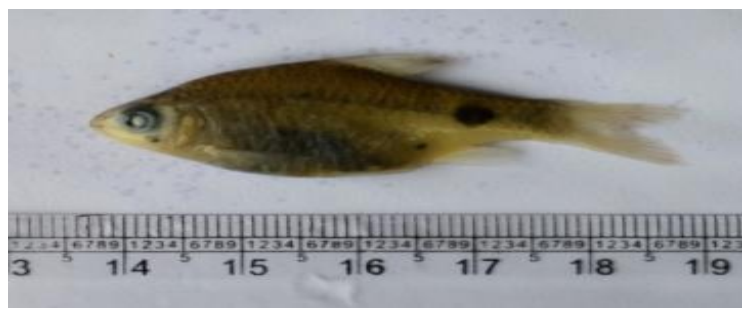

Puntius terio

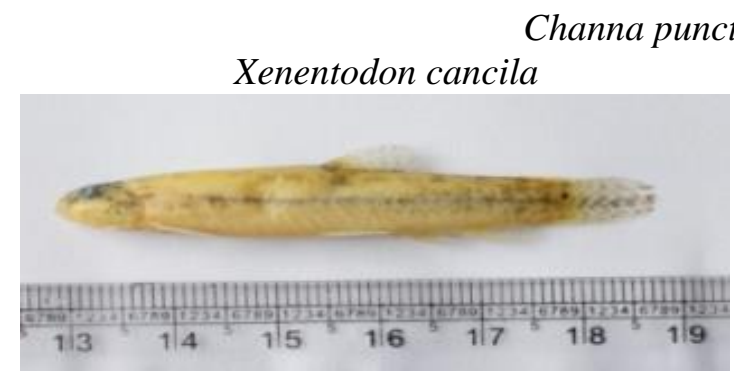

Lepidocephalichthys guntea

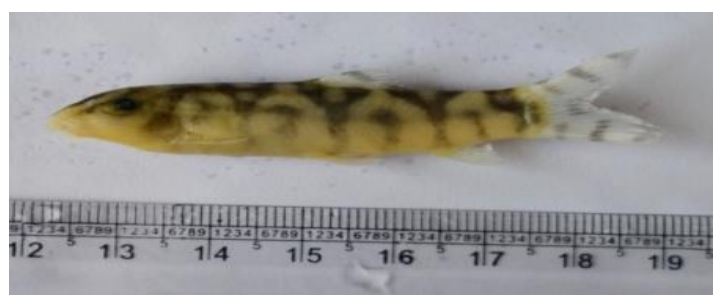

Botia lohachata

Figure 5. Fishes of West Rapti River.

\section{Conclusion}

The Canonical Correspondence (CCA) analysis hinted that water temperature and dissolved oxygen act as essential variables in shaping the fish assemblage structure of West Rapti River.

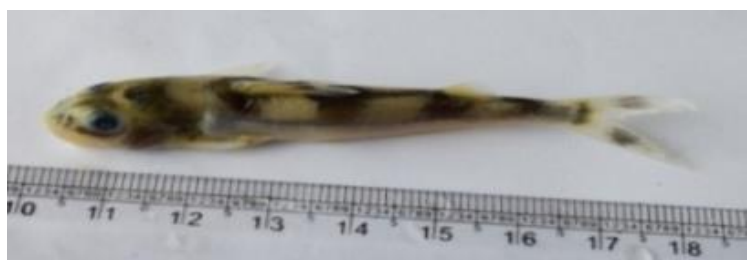

Gagata cenia

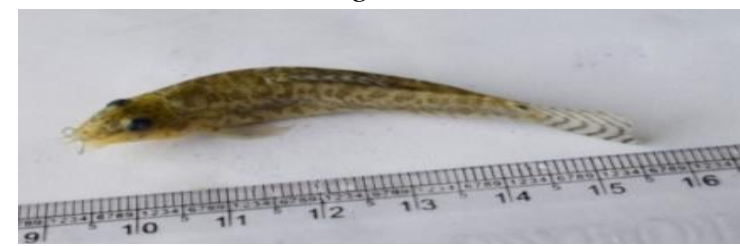

Paracanthocobitis botia

Puntius sophore

IEZIRF
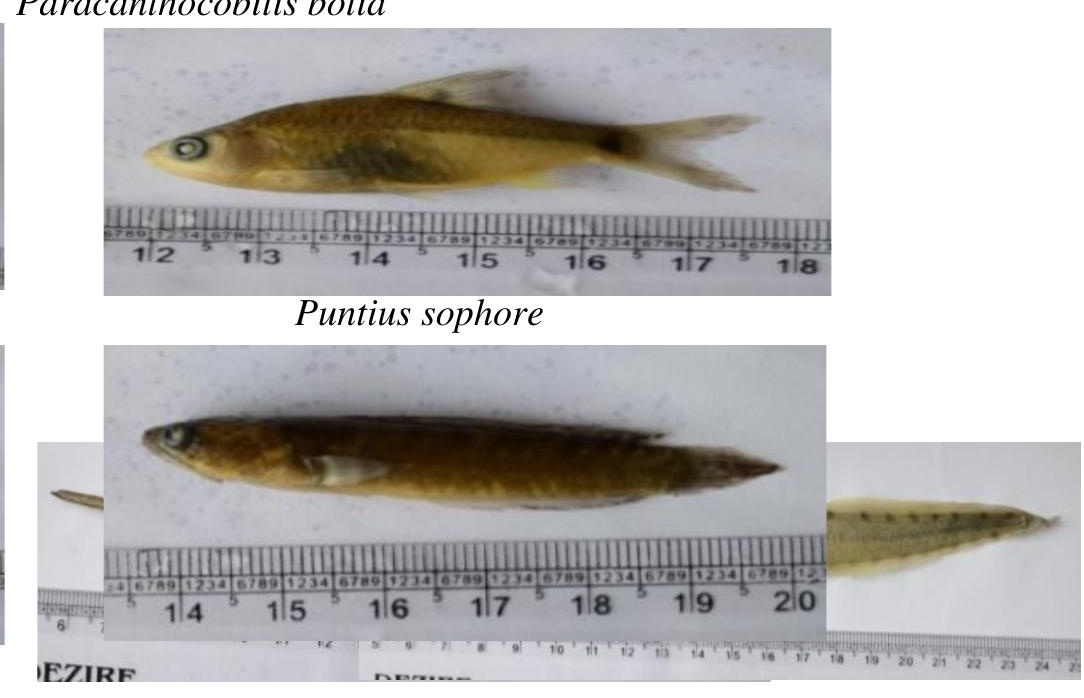

Macrogonathus aral

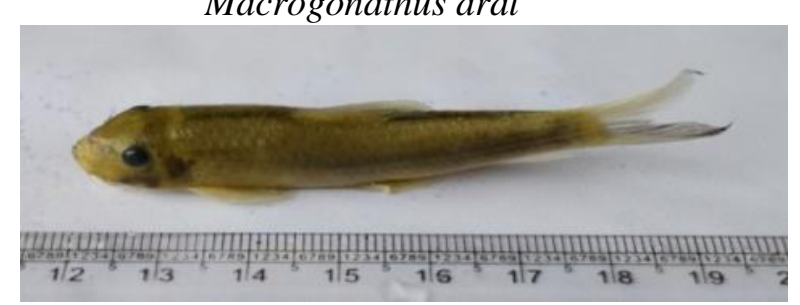

Garra gotyla

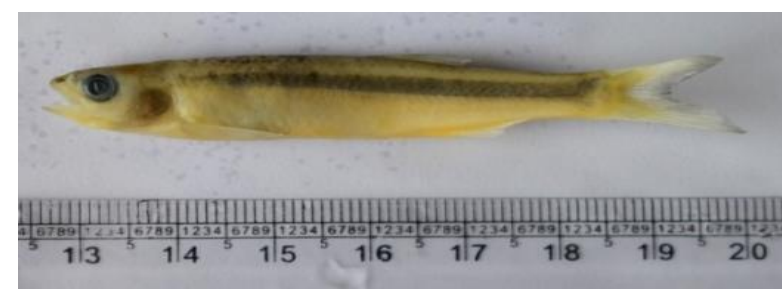

Rasboradanioconius

The populations of Tor putitora, Rasbora danionius, Lepidocephalichthys guntea, Xenentodon cancila, Pseudombassis baculis,Macrogonathus armatus, Channa punctata and Glossogobius 


\section{Our Nature | December 2020 | 18 (1): 28-37}

giuris were found to be declining in the West Rapti River. The present study therefore, foresees the need of an immediate conservational initiative to conserve the above mentioned species in the river.

\section{Acknowledgement}

The authors express sincere gratitude to Prof. Dr. Tej Bahadur Thapa, HOD, Central Department of Zoology (CDZ), Tribhuvan University for meticulous supervision and motivation to carryout the proposed work. The authors are grateful to Mr. Jitendra B.K. for assisting in the sample collection.

\section{References}

Brown L.R. 2000. Fish communities and their associations with environmental variables, lower San Joaquin River drainage, California. Environ. Biol. Fishes, 57, 251-269.

Clarke, K.R. 1993. Non parametric multivariate analyses of changes in community structure. Australian Journal of Ecology 18, 11743.

Eaton J.G. and Scheller R.M. 1996. Effects of climate warming on fish thermal habitat in streams of the United States. Limnol. Oceanogr.,41, 1109-1115.

Ferreira, F.C. and Petrere, M. 2009. The fish zonation of the Itanhaem river basin in the Atlantic Forest of southeast Brazil. Hydrobiologia, 636: 11-34.

Feyrer F. and Healey M.P. 2003. Fish community structure and environmental correlates in the highly altered southern SacramentoSan Joaquin Delta. Environ. Biol. Fishes, 66, 123-132.

Fialho A.P. Oliveira L.G.Tejerina-Garro F.L. and de Mérona B. 2008. Fish-habitat relationship in a tropical river under anthropogenic influences. Hydrobiologia, 598, 315-324.

Gasith A. and Resh V.H. 1999. Streams in Mediterranean climate regions: abiotic influences and biotic responses to predictable seasonal events. Ann. Rev. Ecolog. Syst., 30, 51-81.

Gerhard, P. Maraes, R. and Molander, S. 2003. Stream fish communities and their associations to habitat variables in a rain forest reserve in southeastern Brazil. Environ Biol Fish. 71:321-330.

Godinho F.N. Ferreira M.T. and Santos J.M. 2000. Variation in fish community composition along an Iberian river basin from low to high discharge: relative contrib- utions of environmental and temporal variables. Ecol. Freshwater Fish, 9, 22-29.

Grossmann, G.D. Ratajczak, R.E. Crawford, J.M. and Freemann, M.C. 1998. Assemblages organization in stream fishes: effect of environmental variation and interspecific interactions. Ecological Monograph,68: 395-420.

Ibanez C. Oberdorff T. Teugels G. Mamononekene V. Lavoué S. Fermon Y. Paugy D. and Toham A.K. 2007. Fish assemblages structure and function along environmental gradients in rivers of Gabon (Africa). Ecol. Freshwater Fish, 16, 315-334

Jackson D.A. Peres-Neto P.R. and Olden J.D. 2001. What controls who is where in freshwater fish communities-the roles of biotic, abiotic, and spatial factors. Can. J. Fish. Aquat. Sci., 58, 157-170.

Jayaram, K.C. 2010. The freshwater fishes of Indian region. Narendra Publishing House, Delhi, India, 614.

Kadye, W.T. and Moyo, N.A.G. 2007.Stream fish assemblage and hasbitat structure in a tropical African river basin (Nyagui River, Zimbabwe). African Journal of Ecology 46: 333-340.

Lammert M. and Allan J.D. 1999. Assessing biotic integrity of streams: effects of scale in measuring the influence of land use/cover and habitat structure on fish and macroinvertebrates. Environ. Manage.,23, 257-270.

Limbu, J.H. Acharya, G.S. and Shrestha, O.M. 2016. A brief report on ichthyofaunal diversity of DewmaiKhola of Ilam district, Nepal. J. Nat. Hist Mus. Vol. 30. 312-317.

Limbu, J.H. Baniya, C.B. Prasad, A. 2019a. Spatio-Temporal Variation of Fish Assemblages in Ratuwa River, Ilam, Nepal. $J$ Ecol\& Nat Resour 3(3): 000168.

Limbu, J.H.Chapagain, N. Gupta, S. and Sunuwar, S. 2019b. Review on fish diversity of eastern Nepal. International Journal of Fisheries and Aquatic Studies. 7(3): 177181.

Limbu, J.H. Prasad, A. and Shrestha, Om.H., 2018. Ichthyofaunal diversity of Bakraha River of Morang district, Nepal. International Journal of Fisheries and Aquatic Studies. 6(5): 267- 271

Magalhaes, M.F. Batalha, D.C. and CollaresPereora, M.J. 2002. Gradients in stream fish assemblages across a Mediterranean landscape: contributions of environmental factors 


\section{Our Nature | December 2020 | 18 (1): 28-37}

and spatial structure. FreshwBiol47: 1015 1031.

Marshall, S. and Elliott, M. 1998. Environmental influences on the fish assemblages of the Humber Estuary. U.K. Estuarine, Coastal and Shelf Science 46: 175-184.

Matthews W.J. 1998. Patterns in freshwater fish ecology, Chapman and Hall, Norwell.

Oksanen, J. Blanchet, F.G.Kindt, R. Legendre ,P. Minchin, P.R.Ohara, R.B. Simpson, G.L.Solymos, P. Henry, M. Stevens, H et al. 2015. vegan: Community ecology package. $\mathrm{R}$ package version 2.3-1. Available from: http://CRAN.R-project. org/package vegan

Oli, T.B. 2016. Fish Diversity of West Rapti River, Dang, Nepal.M.sc. Dessertation Central Department of Zoology, Tribhuvan University, Kathmandu, Nepal.

Platts W.S. 1979. Relationships among stream order, fish populations, and aquatic geomorphology in an Idaho river drainage. Fisheries, 4, 5-9.

Poff N.L.R. and Allan J.D. 1995. Functional organization of stream fish assemblages in relation to hydrological variability. Ecology, 76, 606-627.

Pokharel, K.K.Khadga, B. B.Trilok, C. M. and Chitra B. B. 2018. Correlations between fish assemblage structure and environmental variables of the SetiGandaki River Basin, Nepal, Journal of Freshwater Ecology, 33:1, 31-43, DOI: 10.1080/02705 060.2017.1399170.

Shahnawaz A. Venkateshwarlu M. Somashekar D.S. and Santosh K. 2010. Fish diversity with relation to water quality of Bhadra
River of Western Ghats (INDIA). Environ. Monitor. Assess.,161, 83-91.

Shrestha, T.K. 2019. Ichthyology of Nepal, A study of fishes of the Himalayan waters. Himalayan Ecosphere, Kathmandu, Nepal.

Subba, B.R. Pokharel, N. and Pandey, M.R. 2017. Ichthyofaunal diversity of Morang district, Nepal. Our Nature. 15(1, 2):55-67. DOI: htt:/dx.doi.org/10.3126/on.v15il-2.187 94.

Talwar, P.K. and Jhingram, A.G. 1991. Inland Fisheries of India and Adjacent Countries. Volume I and II. Oxford and IBH Publishing Co. India, 1158.

Tejerina-Garro F.L. Fortin R. and Rodriguez M.A. 1998. Fish community structure in relation to environmental variation in floodplain lakes of the Araguaia River, Amazon Basin. Environ. Biol. Fishes, 51, 399-410.

terBraak, C.J.F. 1986. Canonical correspondence analysis-a new eigenvector technique for multivariate direct gradient analysis. Ecology 67(5): 1167-1179.

Vlach, P. Dusek, J.Svatora, M. Moravec, P. 2005. Fish assemblage structure, habitat and microhabitat preference of five species in a small stream. Folia Zool54: 421-431.

Yan, Y.,Shan, H.E. Ling, C.H.U. Xiuying, X. Yanju, J.I.A. Juan, T.A.O. Yifeng, C. 2010. Spatial and temporal variation of fish assemblages in a subtropical small stream of the Huangshan Mountain. Current Zoology: 56(6): 670-677.

$\mathrm{Yu}$, S.L. and Lee, T.W. 2002. Habitat preference of the stream fish, Sinogastromyzonpuliensis.Zool Stud 41: 183-187. 